\title{
DR. JAMES SIMS (174I-I820): A NEW APPRAISAL
}

by

\author{
CUTHBERT E. DUKES
}

JAmes Sims, M.D. ( $174 \mathrm{I}-1820$ ) is of historical interest chiefly because he was indirectly responsible for the formation of the Royal Society of Medicine. Sims had been President of the Medical Society of London since I786 and had obstinately held on to this office year after year until finally in 1805 a group of twenty-six exasperated Fellows resigned and formed a new body, to be known as The Medical and Chirurgical Society of London, from which the Royal Society of Medicine may trace its direct descent.

The avowed objects of this 'splinter group' were

to found a society comprehending the several branches of the medical profession in London for the purpose of conversation on professional subjects, for the reception of communications and the formation of a library.

The secessionists established a rule at their first meeting on 22 May 1805 , declaring that 'No gentlemen be eligible to the office of President or Vicepresident for more than two years in succession.' A slap at Sims!

The new society was granted a charter by William IV in 1834 and became known as the Royal Medical and Chirurgical Society of London. Meanwhile, in the first half of the nineteenth century, a number of other medical societies were formed representing different branches of medicine and it was the voluntary federation of these with the oldest and largest group, The Royal Medical and Chirurgical Society, which resulted in the formation of the Royal Society of Medicine in 1907.

James Sims is remembered also because whilst still President he sold his library to the Medical Society of London in return for a lump sum in cash and a small annuity for his wife and himself: a strange transaction!

These two episodes, his long tenure of the presidential chair and the deal over his library, have had the effect of making Sims appear as a dubious character, a sort of 'wicked uncle' within the family circle. Since very little else has been recorded about Sims he has been judged on these two incidents alone, somewhat harshly, I think, and without sufficient allowance for the different customs and standards of a hundred and sixty years ago.

In search of further information about James Sims I have looked through the Minute books of the Medical Society of London from its foundation in 1773 to the termination of the presidency of Sims in 1808, read his communications to the Medical Society and other published work and searched for references to Sims by contemporary writers. This experience has convinced me that this 'dubious character' or 'wicked uncle' is due for a new appraisal. 
Before proceeding further I should perhaps point out that our James Sims (1741-1820) is not to be confused with James Marion Sims (1813-83) the surgeon-practitioner of Alabama, the inventor of the Sim's Speculum, who is commemorated by the fine statue in the park opposite to the New York Academy of Medicine. Our James Sims is remembered only for his long tenure of the office of President of the Medical Society of London and the peculiar circumstances attending the sale of his library.

\section{Life and Character}

James Sims was born in Ireland, in the county of Down, in 1741 . He was the son of a dissenting minister, received a good preliminary education, studied medicine in London and Edinburgh and obtained the degree of Doctor of Medicine at Leyden in 1764 . He then returned to Ireland and settled at Tyrone where he practised for a few years, an experience which provided the material for his first book, published in 1773 . He must have settled in London shortly before this because he joined the Medical Society of London in the same year.

Sims was admitted a licenciate of the Royal College of Physicians in 1778 and later appointed to the General Dispensary in Aldersgate Street and the Surrey Dispensary. He was elected President of the Medical Society in 1786 and held this office for the astonishingly long period of twenty-two years.

He possessed a valuable collection of books, which he made over to the Medical Society in 1802, in consideration of a cash payment of $£ 500$ and an annuity of $£_{15}$ a year to be paid to himself and his wife. He retired to Bath in 1810 where he died in 1820 .

The note in the Dictionary of National Biography says of Sims that he was

a good-humoured pleasant man, full of anecdote, an ample reservoir of good things, and for figures and facts a perfect chronicle of other times.

A reference to him in a book entitled $A$ picture of the present state of the Royal College of Physicians published in 1817 says:

In estimating Sims's merit as a physician he may justly be regarded as a man of abilities and science, cool and shrewd in his temper, and looking deep into the business of life and manners, as well as professional policy.

The writer of the article in Munk's Roll says that:

He had a most retentive memory, but when that failed in any particular he referred to a book of knowledge in the shape of a pocket-book, from which he quoted with oracular authority.

He was described by William Wadd in Nugae Canonae (1827) as

a man of learning and great good humour, but strangely tinctured with vanity about his person which he thought irresistible. [Wadd continues] it was not till late in life that he succeeded in obtaining the hand of a young and fair lady, who, strange to say, was not blind, but deaf! 


\section{Dr. James Sims (I74I-1820): a New Appraisal}

A portrait of Sims was painted by Samuel Medley, and engraved by Branwhite. In Medley's famous picture of the Founding of the Medical Society Sims is represented as seated in the Presidential chair and wearing a cocked hat on his head. Actually he was responsible for this picture because he was a close friend of Medley's and was so pleased with the earlier portrait that he commissioned the artist to paint this picture in the year 180o. At his death in $1820 \mathrm{James}$ Sims bequeathed this precious trophy to the Medical Society of London and it hangs in its Meeting Room in No. II Chandos Street at the present time.

\section{His Writings}

His experience of a country practice in County Tyrone in the I76os provided the material for his first book entitled Observations on Epidemic Disorders with remarks on Nervous and Malignant Fevers. In this he endeavoured to trace a relationship between climate and the incidence of epidemic diseases in the locality in which he had practised. Each chapter in this short book begins with a general description of the weather, particularly the amount of rain, wind and frost, followed by an account of the commonest complaints met with in the succeeding months.

In many ways this is a disappointing book. It consists of rather a monotonous account of various diseases with very little detail about individual patients. Had there been more about patients and less about diseases, the book would have been much more readable. The almost complete absence of any information about Sims himself, his home, his journeys and his remuneration makes me think that the book was probably written a considerable time after the events described and based on general recollections, awakened perhaps by notes of a few cases. Unfortunately this is not in any sense a diary; only a casual collection of reminiscences of little medical or historical interest.

Though Observations on Epidemic Disorders has long been forgotten it must have made an impression at the time of its publication because almost immediately this young Irishman, recently settled in London, was appointed to give the Oration to the newly founded Medical Society at the end of its first session. He chose as his subject The best method of prosecuting medical enquiries and delivered his lecture on 18 January 1774 .

He began by referring to the opinions of Stahl (1660-1734), Hoffman (1660-1 742), Boerhaave (1668-1 738) and other well known eighteenth-century 'systematists', whom he quotes and criticizes freely. He sees the 'systematist' as if

living in a narrow cell, hedged in on all sides by his system [and declares that] his timorous soul dares not look beyond it, lest he might chance to spy anything which should create in him a doubt of his darling hypothesis.

But he does admit that theoretical knowledge may have some slight value but only 'if used as the servant of practice'. 


\section{Cuthbert E. Dukes}

The main theme of this discourse is to emphasize the superiority of knowledge based on practical experience over that derived from hypothesis or theory only. The Oration ends with a long rhetorical passage, in flowery language, comparing the relative merits of the theoretical and the practical doctor concluding with this sentence:

The choice is then in us, and may we, scorning the artful blandishments of theory, attach ourselves only to experience, sensible that in so doing we shall best fulfil our duties, as useful physicians and good men.

A second book by Sims entitled The Principles and Practice of Midwifery appeared eight years later in 178I. The basis of this was a series of lectures prepared by Dr. Edward Foster, a teacher of midwifery in Dublin, who had died before the book was finished. Sims completed and edited this work as a tribute to the memory of his friend, although he says in the preface that he does not claim to be an expert in the subject. In fact he confessed that twenty years had elapsed since midwifery formed part of his medical education and during this time he had 'carefully avoided the practise of it'!

Between the years 1786 and 1813 Sims frequently read papers to the Medical Society of London, most of which were subsequently published in its Memoirs. His contributions extend over a wide variety of subjects including observations on deafness due to affections of the Eustachian tube, two descriptions of epidemics of scarlatina anginosa, articles on the treatment of jaundice, on his method of performing paracentesis, on cow-pox, on the internal use of silver in the treatment of epilepsy, and a paper giving a clinical description of different forms of insanity. These show that Sims was an experienced practitioner, with an Irish wit and a fund of good stories.

A fair sample is his account of the severe epidemic of scarlatina anginosa which appeared in London in 1786 , in which he says that he always began treatment by giving the patient

the most solemn assurances of safety [and, he continues] Here let me mention that the chitchat at the patient's bodside is often neglected and condemned by young practitioners who think it beneath a man of science: yet, I will venture to affirm, that it is often of as much importance as all the medicines that can be administered, and that there is no old steady practitioner who has not saved many patients by it.

Another example might be taken from a paper on the cure of jaundice in which he refers to a mode of treatment in vogue in Ireland, recommended by the Rev. Philip Skelton, whom Sims describes as 'that best of men, the adviser of my early youth and friend of my maturer age'. The Rev. Skelton had eulogized a certain well or pool in the county of Monaghan which he maintained possessed miraculous powers for the treatment of jaundice. The patient was recommended to sit in the pool whilst water was poured over his head and body, after which he was put to bed in a neighbouring house until a profuse sweat broke out. Sims says that another part of the ritual which 'might not also 


\section{Dr. James Sims (I74I-I820): a New Appraisal}

be without its use consisted of the superstitious rite of hanging up a rag torn from the patient's clothes upon a neighbouring alder tree'!

Sims goes on to describe two cases of jaundice which he had recently met with in his practice in London for which he decided to try the 'bog water' treatment. The first patient was treated successfully by the genuine well water sent over in bottles from Ireland. In the second case the treatment was also successful though in this the 'bog water' was not sent from Ireland but was derived from what Sims describes as 'an unspecified source'!

\section{The Sale of his Library}

To understand the strange transaction whereby Sims sold his library to the Medical Society it should first be mentioned that when this Society was founded in 1773 one of its declared objects was the provision of a good medical library. The Minute Book records that at the second meeting of the Society, on 26 May I 773, it was reported that a library had been offered for sale, but at the next meeting the members were told that this library had already gone to a bookseller. From this point onwards the Council Minutes record regularly donations of books and manuscripts, gifts by Sims being often mentioned. Later, in 1787 , the Society began to publish printed Memoirs and at the end of each of these six volumes covering the years $1787-1805$ there is a long list of books given by Fellows and here again there are references to donations by James Sims. I mention this, first to show that it was the deliberate policy of the Society to collect books, and secondly to point out that Sims himself was a frequent and generous benefactor.

During the first year of the Presidency of Sims the Medical Society was meeting in cramped quarters in Crane Court, but in 1787 soon after Sims began his second year of office, Lettsom, the Founder of the Society, came forward with his munificent gift of the freehold of a spacious house in which, besides rooms for meetings and other purposes, there was ample accommodation for a big library. This was at No. 3 Bolt Court, Fleet Street, to which address the Society moved in 1788 .

The preface to the second volume of the Memoirs published two years later states that 'The Society having founded a medical library, donations to promote the object of their institution will be gratefully accepted' but it seems that the new acquisition of books, though substantial, was insufficient to fill the space available in the new quarters.

The first mention of the purchase of the President's library is found in the Minutes of the Council held on 30 December I 799, where it is reported that

Dr. James Sims had proposed the Society should be put into possession of such books belonging to him (copies of which were not already in their library) . . . comprehending not fewer than 8000 volumes subject to the condition of the Society's paying an Annuity of $£ 60$ per annum during the joint lives of Dr. \& Mrs. Sims and an Annuity of $£ 90$ per annum to the survivor of them during his or her life: Dr. Sims should bear half the expense of their removal and fitting up in cases. [The Minute continues] Resolved that it would be highly advantageous to accept the above proposal of Dr. Sims if consistent with the Society's finances. 


\section{Cuthbert E. Dukes}

Then six months later at a meeting on 2 June 1800 , it was decided to ask Sims if he would accept $£ 500$ and an annuity of $£ 3^{\circ}$ during the life of Dr. and Mrs. Sims, and 'that of the survivor of them'. A week later it was reported that Sims had accepted this.

At the Meeting of the Council on 30 June 1800 , a further letter was read from Sims as follows.

In order to bring the treaty to a conclusion I beg leave to make you the following offer. By the original agreement $I$ was to be at half the expense of shelving the library, instead of this if the $£ 500$ be paid in before the first of October I will give up the whole of my first year's Annuity of $£ 30$ and also all the shelves in one of my libraries.

At this meeting Dr. Lettsom offered to make a substantial contribution to complete the subscription of $£ 500$.

Sims wrote again a letter read at the Council Meeting on 27 October I800, asking for completion of payment within a week. The Council at this meeting took steps to comply with Sims's request.

There is no further reference to the Library for the next two years but then it was discovered that the library contained not 8000 volumes as had been stated but less than 6000 and that several of the most valuable books were reported to be imperfect. The library committee, which contained a number of Fellows who were discontented with the long presidency of Sims, communicated this information to the Council with some caustic comments.

In answer to this Sims agreed on 6 October 1802 to accept the $£ 500$ already paid to him and an Annuity of $£ 15$ a year instead of the $£ 30$ previously mentioned, and these were the terms of the final settlement.

The preface to the sixth volume of Memoirs (published in 1805) proudly states that

the library in possession of the Society now contains upwards of ten thousand volumes of singular rarity and value which are always accessible to its members.

Judged by modern standards it was of course a most irregular procedure for a President to sell his private library to the Society over which he presided, particularly if the terms of the transaction made him into the Society's pensioner! I am not attempting to justify it but only to point out that there were 'extenuating circumstances' for this irregular deal in that it was the declared policy of the Society to provide a library, and the recently acquired new premises had space available for many more books. I have tried to find out if there were any circumstances in Sims's life at this time which made him wish for any reason to get rid of some of his big collection of books but $I$ have not been able to ascertain any facts other than that he married rather late in life. This may or may not have had anything to do with it. Possibly it may have been only a matter of convenience when moving house, an occasion when old books are often a problem. Anyhow, whatever the reason for the proposal to sell his library to the Medical Society, I want to make it quite clear that Sims was not driving a hard bargain: on the contrary the books and manuscripts were certainly worth a great deal more than was paid for them. 


\section{Dr. James Sims (I74I-1820): a New Appraisal}

No complete list of the books and manuscripts in the Sims collection has been preserved. The first catalogue of the Library of the Medical Society I have been able to find is the one printed in 1828 but this includes many other books, some acquired before and others after the Sims collection. In 1838 Dr. Severn, whilst browsing amongst the older books, found one entitled 'Diary of the Rev. John Ward of Stratford' covering the years $1647-73$ and noticed in it 'some curious matter relating to Shakespear!' It was the opinion of Dr. Severn that this particular book had formed part of the collection of books purchased from Sims and Sir D'Arcy Power, who made a close study of this diary many years later, was of the same opinion. (Trans. Med. Soc. Lond. 1917. xL 4). Since the Diary of John Ward was more of Shakespearian than of medical interest, the Council in 1928 decided to sell this book and it was sold by auction to an American bidder for ten thousand pounds!

Part of the money obtained from the sale of the John Ward Diary was used for rebinding old books in the library and the preparation of a new card index catalogue. In the course of this work several more treasures were discovered including a 1639 edition of Harvey's de Motu Cordis, a copy of Gardiner's Triall of Tobacco (1610), King James's Counterblast to Tobacco (2nd ed. 1608) and a rare copy of Vesalius's Anatomy (I539). How many of these belonged to the original Sims collection is not known.

In 1932 a descriptive Catalogue of the Manuscripts in the Library was compiled by Dr. Warren R. Dawson, who reported that most of the manuscripts had been in the Society's possession since its earliest years, and the actual source of the majority could not be ascertained.

\section{His Long Tenure of Presidency of the Medical Society}

Sims was elected President of the Medical Society in the year I786 and continued in this office for twenty-two years. He was re-elected annually, sometimes in rather a perfunctory fashion, until 1808 when he submitted his resignation in writing and declined to stand again. Before the presidency of Sims it had been the custom to elect a new President each year and after Sims this rule has been strictly observed. Why was it then that James Sims was allowed to occupy the presidential chair for so many years?

To answer this question we must recall again that when Sims was elected President in 1786 the Society was in very low water. It was torn by feuds and dissensions. The membership was declining and there was even talk of dissolution. The meetings, such as they were, took place in a room in Crane Court, Fleet Street, where the accommodation was unsuitable and the tenancy uncertain. More than one of Sims's predecessors in the presidential chair had been dismal failures. The Society was heavily in debt. Twenty-two years later in his letter of resignation (dated I I November 1808 ) Sims wrote when referring to his first election that he had been elected 'out of turn' by which I assume that he meant that there were other more senior candidates but he was deliberately chosen because it was a time of crisis when ordinary rules of procedure could be suspended. A 'strong man' was needed and Sims seemed to be the man. 


\section{Cuthbert E. Dukes}

There is no doubt that at first he was a good choice. Order and confidence were restored. The attendance at meetings improved. New members joined and at the end of his first year of office Sims was enthusiastically re-elected and the rules of the Society altered to make this possible.

Lettsom himself must have been persuaded that things were on the mend because it was in the second year of Sims's presidency that he presented the Society with the freehold of a spacious house with ample accommodation both for meetings and for a library. This initiated a new phase in the development of the Society, a new chapter in its history.

There does not seem to have been any dissatisfaction with Sims until he had been in office for seventeen to eighteen years, though there had been some criticism in connexion with the sale of the President's library, it being suggested that the books actually received were fewer in number and of less value than represented by Sims. But the first organized revolt found expression in February 1805 when it was proposed at a meeting of the Council that:

No gentleman shall be eligible for the office of President who shall have served in that capacity during the whole of the three preceding years.

This resulted in the calling of a Special General Meeting at which after stormy scenes Sims and his faction won the day but it was followed by many resignations and within a few days twenty-six of the secessionists had formed a new Society, The Medical and Chirurgical Society of London.

Following this there were many more resignations. Sims hung on obstinately for three more years and did not officially resign until i I November I808. His letter of resignation and the events that led up to it are given in detail in Johnston Abraham's Life of Lettsom. Dissatisfaction arising from Sims's long tenure of the presidency was certainly the main cause of the formation of the Medical and Chirurgical Society but it was not the only one. As already mentioned, in a book published in 1817 entitled $A$ picture of the present state of the Royal College of Physicians, there is a short memoir of James Sims which perhaps contains a few inaccuracies but is of interest because of its comments on the dissensions which led to the formation of the Medical and Chirurgical Society. It says that the Medical Society of London had become 'too numerous in its members and it is alleged not so select at all times'. From this cause it says that dissensions arose but there is no reference to Sims's long tenure of the office of President, though these comments must have been written only eight or nine years after his resignation when memories were still fresh. The Medical and Chirurgical Society was said to be

a more elevated establishment which was formed purposely with a view to exclude the lower order of the profession!

Again no mention of the long Presidency: only the creation of a more select body.

The formation of the Medical and Chirurgical Society undoubtedly injured the Medical Society but did not ruin it. Upheavals like this are sometimes $3^{82}$ 


\section{Dr. James Sims (I74I-1820): a New Appraisal}

useful and within a few years the Medical Society seems to have recovered its balance, for in the early 1830 it was said 'to number amongst its Fellows most of the distinguished members of the Profession'. Debates were said to be carried out with great spirit and it was likened to the House of Commons of the Medical Profession. (Med. Times and Gazette, 18 December 1869. Obituary notice to Edward Headland.)

The influence of James Sims might be summarized by saying that his assumption of the Presidency in 1786 saved the Medical Society of London and that his retention of the office for twenty-two years nearly shipwrecked it. Indirectly he was responsible for the coming to birth of the Medical and Chirurgical Society which in due course became the Royal Society of Medicine.

A saying, attributed to $\mathrm{St}$. Thomas Aquinas, runs 'It is the last perfection of a thing that it should be the cause of other things'. By this I suppose he meant that it would be the 'last perfection' of a flower if its ripened seed should be the 'cause' of bringing forth other flowers. If this be so, the soul of Sims may rest in peace. Both the Medical Society of London and the Royal Society of Medicine have blossomed from his ashes.

The Editor regrets that in the article by Dr. Wright-St. Clair, in the July number of Medical History, the footnotes on page 287 and 288 were transposed. The first two footnotes on page 288 should come at the foot of page 287 and the footnotes on page 287 transferred ta page 288. 